Article

\title{
Effects of Amending Phosphatic Fertilizers with Clinoptilolite Zeolite on Phosphorus Availability and Its Fractionation in an Acid Soil
}

\author{
Nur Aainaa Hasbullah ${ }^{1,2, * \mathbb{C}}$, Osumanu Haruna Ahmed ${ }^{2,3,4}$ and Nik Muhamad Ab Majid ${ }^{4}$ \\ 1 Faculty of Sustainable Agriculture, University Malaysia Sabah, Locked Bag No 3, \\ 90509 Sandakan, Sabah, Malaysia \\ 2 Department of Crop Science, Faculty of Agriculture and Food Sciences, Universiti Putra Malaysia, Bintulu \\ Sarawak Campus, 97008 Bintulu, Sarawak, Malaysia; osumanuharuna@gmail.com \\ 3 Institute of Tropical Agriculture and Food Security (ITAFoS), Universiti Putra Malaysia, 43400 Serdang, \\ Selangor, Malaysia \\ 4 Institute of Tropical Forestry and Forest Product (INTROP), Universiti Putra Malaysia, 43400 Serdang, \\ Selangor, Malaysia; nikmatmajid.upm@gmail.com \\ * Correspondence: aainaa.hasbullah@ums.edu.my
}

Received: 22 March 2020; Accepted: 16 April 2020; Published: 1 May 2020

\begin{abstract}
Soils of the tropics are highly weathered, acidic, and low in phosphorus (P) because of high contents of $\mathrm{Al}$ and $\mathrm{Fe}$. Satisfactory $\mathrm{P}$ supply is essential to ensure optimum soil and crop productivity. Thus, there is a need for amending soils with zeolite to improve availability of $\mathrm{P}$ in acid soils as this mineral can fix $\mathrm{Fe}$ and $\mathrm{Al}$ instead of $\mathrm{P}$. This study was undertaken to determine the transformations of $P$ fertilizers in acid soils following application of Clinoptilolite zeolite (CZ) in laboratory (incubation) and pot trials. An acid soil was incubated with a recommended fertilization rate and a reduced amount of the existing recommended fertilization by $25 \%$ but substituting this reduction with an equivalent amount of CZ. Triple superphosphate (TSP), Egypt Rock phosphate (ERP), and Christmas Island Rock phosphate (CIRP) were used as $\mathrm{P}$ sources. Selected soil chemical properties, inorganic $\mathrm{P}$ fractions, available $\mathrm{P}$, and total $\mathrm{P}$ of the native soil were determined before and after the laboratory and pot trials. Zea mays L. (test crop) plant dry matter production, $\mathrm{P}$ concentration, $\mathrm{P}$ uptake, and $\mathrm{P}$ use efficiency were also determined using standard procedures. Effects of the treatments with $\mathrm{CZ}$ compared to the recommended fertilization on P fixation were similar. In the laboratory study, the treatments with TSP showed lower dominance of $\mathrm{Fe}-\mathrm{P}$ but more pronounced in $\mathrm{Al}-\mathrm{P}$, whereas for the RPs, Ca-P was dominant. In the pot study, Al-P, Ca-P, and Fe-P were rather pronounced in the treatments with TSP, ERP, and CIRP, respectively. There was a decrease in exchangeable $\mathrm{Al}$ and soil titratable acidity because of the ability of the $\mathrm{CZ}$ to increase soil $\mathrm{pH}$. Although the availability of $\mathrm{P}$ was not significant with the inclusion of $\mathrm{CZ}$ in the incubation study, dry matter production, $\mathrm{P}$ concentration, $\mathrm{P}$ uptake, and $\mathrm{P}$ use efficiency in the pot trial were comparable with that of the existing/recommended fertilization, suggesting that the $\mathrm{CZ}$ is beneficial and could be used to reduce the $\mathrm{P}$ fertilizer requirement for Zea mays L. cultivation on acid soils. Regardless of type of $\mathrm{P}$ fertilizer, prevalence of the moderately labile $\mathrm{P}$ fractions (Al-P, Fe-P, and $\mathrm{Ca}-\mathrm{P}$ ) of the incubation and pot studies acted as slow-release $P$ sources to contribute to long-term $P$ release. Further studies on the potential of $\mathrm{CZ}$ to reduce fertilization and its effects on soil and crop productivity are essential. It is also important to determine the economic benefits of including CZ in Zea mays L. cultivation.
\end{abstract}

Keywords: phosphorus speciation; tropical acid soils; phosphorus fractions; clinoptilolite zeolite; phosphorus fixation 


\section{Introduction}

Phosphorus is one of the essential macronutrients that crops need for their growth and development. Adequate supply of $P$ from the early growth stage of crops is vital for crop general health, improvement of crop quality, and optimum crop productivity. Phosphorus deficiency may limit crop yield, whereas build-up of excess P may cause P leaching and eutrophication of water bodies.

In acid soils of the tropics, intense weathering of Ultisols and Oxisols which is influenced by high rainfall and temperature throughout the year results in low soil $\mathrm{pH}$ (ranges from 4 to 5), high leaching of bases, and replacement of bases in the with $\mathrm{Fe}$ and $\mathrm{Al}$. Another consequence of intense weathering of these soils is that with time they become low in P availability with a high P fixing capacity because of their richness in $\mathrm{Fe}$ and $\mathrm{Al}$ ions which are known to have high affinity for $\mathrm{P}$ through a chemical reaction called $P$ fixation. Thus, a large amount of $P$ fertilizers are applied to saturate the capacity for P sorption with the ultimate aim of ensuring $P$ availability for optimum crop uptake. However, this practice in agriculture is neither economically nor environmentally friendly. An evidence being that only $10-20 \%$ of $\mathrm{P}$ applied is available for crop uptake, whereas the remaining soil $\mathrm{P}$ (residual $\mathrm{P}$ ) is adsorbed on soil constituents. Eventually, this could lead to a build-up of soil P capital in the year of application. Residual $\mathrm{P}$ is partitioned into different fractions and pools [1], namely, labile, moderately labile, moderately recalcitrant, available, and total $\mathrm{P}$ fractions. These $\mathrm{P}$ fractions' mobility, bioavailability, and chemical reactions may be remarkably different and can be transformed under certain conditions [2]. Thus, it could potentially infer distinct negative impacts on the environment as bioavailability for crops.

Phosphatic fertilizers which originate from weathering of rocks are limited in reserves and might be depleted in 50-100 years [3-6]. Responses to P scarcity may include increased cost, more efficient $\mathrm{P}$ use, $\mathrm{P}$ recovery, and $\mathrm{P}$ re-use. Moreover, prolonged use of chemical fertilizers in agriculture degrades soil fertility. Therefore, an effective management of $\mathrm{P}$ fertilizers will promote not only increase in crop yield but it will also reduce costs of production and mitigate environmental pollution besides conserving finite $P$ deposit. Soil amendments being either organic or inorganic materials have been integrated in some agricultural practices. One of the soil amendments is natural zeolite, and Clinoptilolite zeolite (CZ) is the most common and abundant type of zeolites.

Zeolites are natural aluminosilicates which have an infinite three-dimensional crystal structure, a polyedric shape, with a great open cavity [7-9]. These abundant and cheap minerals formed as a result of volcanic activities and have been extensively used in agriculture as soil conditioners, slow-release fertilizers, and soil decontaminants [10]. The use of zeolites and rock phosphate (RP) releases P through an exchange-induced dissolution system [11]. Uptake of cations in crops from CZ leads to vacant exchange sites which are capable of attracting $\mathrm{Ca}^{2+}$ ions. This process lowers the activity of $\mathrm{Ca}^{2+}$ ions from soil solution, thereby inducing dissolution of rock phosphates (RP) as well as producing ammonium ion as a by-product [12-14]. Because zeolites are not easily degraded over time, their persistence in soils improve nutrient retention and release for crop use [15-17]. Moreover, the catalytic ability of $\mathrm{CZ}$ could ameliorate soil $\mathrm{pH}$, consequently reducing soil acidity and concentrations of exchangeable $\mathrm{Al}$ and $\mathrm{Fe}$. This process does not only reduce $\mathrm{P}$ fixation in acid soils but it also ensures an efficient use of nutrients through timely release of nutrients for optimum crop production.

It is possible that, in a long-term application of zeolites, soil properties could be rejuvenated to sustain crop productivity because zeolites can positively change the chemical dynamics of soils. However, there is dearth of information on the effects of $\mathrm{CZ}$ on $\mathrm{P}$ speciation and its distribution in acid soils, such as Ultisols—not to mention a reduction in $\mathrm{N}, \mathrm{P}$, and $\mathrm{K}$ fertilizer usage in agriculture. Therefore, this study was undertaken to determine the $\mathrm{P}$ transformations of $\mathrm{P}$ fertilizers in conjunction with $C Z$ in an acid soil.

\section{Materials and Methods}

This study involved laboratory and pot studies which were conducted at Universiti Putra Malaysia Bintulu Sarawak Campus, Malaysia (UPMKB). 


\subsection{Soil Sampling}

The Bekenu Series (Typic Paleudults) used in the laboratory and pot studies is classified as Ultisols. In Malaysia and elsewhere, this soil is cultivated with different crops although it is high in P fixation due to high $\mathrm{Fe}$ and $\mathrm{Al}$ contents. This is the reason why this soil was used in the two studies. Soil samples were taken from a $20 \mathrm{~m} \times 20 \mathrm{~m}$ of an uncultivated area at UPMKB. The soil samples were taken at $0-15 \mathrm{~cm}$ depth. Coordinates of the soil sampling site are latitude $03^{\circ} 12.241^{\prime} \mathrm{N}$ and longitude $113^{\circ} 04.270^{\prime} \mathrm{E}$. The soil samples were air-dried, ground, and sieved to pass a $2 \mathrm{~mm}$ sieve for physical and chemical characterization, incubation study, and P fractionation, whereas $5 \mathrm{~mm}$ sieved soil was used for the pot study.

\subsection{Physical and Chemical Analysis of Soil, Clinoptilolite Zeolite, and Phosphorus Fertilizers}

Soil texture was determined by measuring the distribution of sand, silt, and clay using the hydrometer method [18]. Soil and CZ pH were determined using a digital pH meter (Seven Easy pH, Mettler-Toledo GmbH, Switzerland) at a ratio of 1:25 (soil:distilled water) [19]. Soil organic matter and total carbon were determined using the loss-on-ignition method [20]. Soil bulk density was determined using the method described in the Soil Survey Staff [18]. Soil total P (extracted using aqua regia) and available $\mathrm{P}$ (extracted using Mehlich No.1) were determined using spectrophotometer (Lambda 25, Perkin Elmer) after blue color development [21,22]. Soil cation exchange capacity (CEC) was determined using the ammonium acetate method [23], whereas exchangeable cations $(\mathrm{K}, \mathrm{Ca}, \mathrm{Mg}$, and $\mathrm{Fe}$ ) were extracted using double acid as extractant following the method of Mehlich No.1 [24]. Cation concentrations were determined using atomic absorption spectrometry (Perkin Elmer AAnalyst 800). Exchangeable soil acidity and $\mathrm{Al}$ were extracted using $1 \mathrm{M} \mathrm{KCl} \mathrm{(1:10} \mathrm{soil/solution)} \mathrm{after} \mathrm{which}$ they were determined using the colorimetric method [25].

\subsection{Phosphorus Fractionation Study}

Series of extractants were used to fractionate different pools of inorganic $\mathrm{P}(\mathrm{Pi})$ following the method described by Kuo [26]. In the sequential extraction, different extractants (Table 1) were added to a $1 \mathrm{~g}$ of soil in succession into a $200 \mathrm{~mL}$ polyethylene centrifuge tube. The suspension was shaken, centrifuged, washed, and fractions of Pi extracted were measured after blue color development [22]. A UV-visible Spectrometer (Lambda 25, Perkin Elmer) at $882 \mathrm{~nm}$ was used for the blue color determination.

\subsection{Laboratory Incubation Study}

In the laboratory incubation study, treatments were incubated for 90 days at $26{ }^{\circ} \mathrm{C}$ (room temperature). The treatments were incubated in a closed system without plant interaction and leaching effect to determine the reaction of the treatments with soil only. From the bulk 2-mm soil sample, 250 $\mathrm{g}$ of soil was weighed into a polypropylene container and adjusted to $60 \%$ of moisture content. The lid of the polypropylene container was perforated to enable good aeration. When necessary, the soil moisture content was maintained using distilled water. The treatments were arranged in a completely randomized design (CRD). The treatments evaluated (Table 2) were surface applied. Before harvest, soil samples were mixed and air-dried for $\mathrm{pH}$, exchangeable cation $(\mathrm{K}, \mathrm{Ca}, \mathrm{Mg}$, $\mathrm{Fe}$, and, $\mathrm{Al})$, soil acidity, total $\mathrm{P}$, available $\mathrm{P}$, and inorganic $\mathrm{P}$ fractionation determination. The recommended rates of the $\mathrm{N}$, $\mathrm{P}$, and $\mathrm{K}$ fertilizers used were $60 \mathrm{~kg} \mathrm{~N} \mathrm{ha}^{-1}$ (130 kg ha ${ }^{-1}$ urea), $60 \mathrm{~kg} \mathrm{P}_{2} \mathrm{O}_{5} \mathrm{ha}^{-1}$ (130 kg ha ${ }^{-1}$ triple superphosphate (TSP): $214 \mathrm{~kg} \mathrm{ha}^{-1}$ Egypt Rock phosphate (ERP): $200 \mathrm{~kg} \mathrm{ha}^{-1}$ Christmas Island Rock phosphate (CIRP)), and $40 \mathrm{~kg} \mathrm{~K}_{2} \mathrm{O} \mathrm{ha}^{-1}\left(67 \mathrm{~kg} \mathrm{ha}^{-1}\right.$ Muriate of potash, MOP). These rates were reduced to per plant basis and they were equivalent to $4.85 \mathrm{~g}$ urea plant $^{-1}, 7.95 \mathrm{~g}$ ERP plant $^{-1}, 7.42 \mathrm{~g}$ CIRP plant $^{-1}, 4.84 \mathrm{~g} \mathrm{TSP} \mathrm{plant}^{-1}$, and $2.47 \mathrm{~g} \mathrm{MOP} \mathrm{plant}^{-1}$ from the standard fertilizer recommendation [27]. Inclusion of urea and MOP in the study was to mimic planting inputs which include these fertilizers to sustain plant growth. The $\mathrm{CZ}$ as an amendment was used to replace $25 \%$ of the amount of fertilizers 
required as recommended. This amount of $\mathrm{CZ}$ used is due to the economic feasibility of this practice which compensates the cost of $P$ fertilizer and liming applied [28].

Table 1. Sequential extraction procedure of inorganic phosphorus.

\begin{tabular}{|c|c|c|c|}
\hline Pi Fraction & Extractant & Extraction Time & Other Condition \\
\hline $\begin{array}{l}\text { A: Sol-P } \\
\text { (Loosely soluble-P) }\end{array}$ & $50 \mathrm{~mL} 1 \mathrm{M} \mathrm{NH}_{4} \mathrm{Cl}$ & $\begin{array}{l}\text { Shake ( } 30 \text { minutes), centrifuge, save } \\
\text { supernatant as A }\end{array}$ & \\
\hline $\begin{array}{l}\text { B: Al-P } \\
\text { (Aluminum bound } \mathrm{P} \text { ) }\end{array}$ & $\begin{array}{l}50 \mathrm{~mL} 0.5 \mathrm{M} \mathrm{NH}_{4} \mathrm{~F} \\
\text { (adjusted to } \mathrm{pH} 8.2 \text { ) }\end{array}$ & $\begin{array}{l}\text { Shake ( } 1 \text { hour), centrifuge, } \\
\text { save supernatant as B }\end{array}$ & $\begin{array}{l}\text { Wash soil residue twice } \\
\text { with } 25 \mathrm{ml} \text { saturated } \\
\mathrm{NaCl} \text { and combine the } \\
\text { washings with B }\end{array}$ \\
\hline $\begin{array}{l}\mathrm{C}: \mathrm{Fe}-\mathrm{P} \\
\text { (iron bound P) }\end{array}$ & $50 \mathrm{~mL} 0.1 \mathrm{M} \mathrm{NaOH}$ & $\begin{array}{l}\text { Shake (17 hours), centrifuge, save } \\
\text { supernatant as } C\end{array}$ & $\begin{array}{l}\text { Wash soil residue twice } \\
\text { with } 25 \mathrm{ml} \text { saturated } \\
\mathrm{NaCl} \text { and combine the } \\
\text { washings with } \mathrm{C}\end{array}$ \\
\hline $\begin{array}{l}\text { D: Red-P } \\
\text { (Reductant soluble P) }\end{array}$ & $\begin{array}{l}40 \mathrm{~mL} 0.3 \mathrm{M} \mathrm{Na}_{3} \mathrm{C}_{6} \mathrm{H}_{5} \mathrm{O}_{7} \\
5 \mathrm{~mL} 1 \mathrm{M} \mathrm{NaHCO}{ }_{3} \\
\text { (add while heating) }\end{array}$ & $\begin{array}{l}\text { Shake ( } 15 \text { minutes), heat in water bath } \\
\left(85^{\circ} \mathrm{C}, 15 \text { minutes) }\right. \\
\text { Add } 1 \mathrm{~g} \mathrm{NaS}_{2} \mathrm{O}_{4} \text {, stir rapidly, and } \\
\text { continue heating ( } 15 \text { minutes). } \\
\text { Centrifuge and save supernatant as } \mathrm{D}\end{array}$ & $\begin{array}{l}\text { Wash soil residue twice } \\
\text { with } 25 \mathrm{ml} \text { saturated } \\
\mathrm{NaCl} \text { and combine the } \\
\text { washings with D }\end{array}$ \\
\hline $\begin{array}{l}\text { E: Ca-P } \\
\text { (Calcium bound } \mathrm{P} \text { ) }\end{array}$ & $50 \mathrm{~mL} 0.25 \mathrm{M} \mathrm{H}_{2} \mathrm{SO}_{4}$ & $\begin{array}{l}\text { Shake ( } 1 \text { hour), centrifuge, } \\
\text { save supernatant as E }\end{array}$ & $\begin{array}{l}\text { Wash soil residue twice } \\
\text { with } 25 \mathrm{ml} \text { saturated } \\
\mathrm{NaCl} \text { and combine the } \\
\text { washings with } \mathrm{E}\end{array}$ \\
\hline $\begin{array}{l}\text { F: Occl-P } \\
\text { (Occluded P) }\end{array}$ & $50 \mathrm{~mL} 0.1 \mathrm{M} \mathrm{NaOH}$ & $\begin{array}{l}\text { Shake (1 hour), centrifuge, } \\
\text { save supernatant as } F\end{array}$ & $\begin{array}{l}\text { Wash soil residue twice } \\
\text { with } 25 \mathrm{ml} \text { saturated } \\
\mathrm{NaCl} \text { and combine the } \\
\text { washings with } \mathrm{F}\end{array}$ \\
\hline
\end{tabular}

Table 2. Treatment evaluated in laboratory incubation study.

\begin{tabular}{|c|c|c|c|c|c|c|}
\hline & \multicolumn{2}{|l|}{ Treatments } & \multirow[t]{2}{*}{ P Fertilizer } & \multirow[t]{2}{*}{ Urea } & MOP & $\begin{array}{c}\text { Clinoptilolite } \\
\text { Zeolite }\end{array}$ \\
\hline & T0 & $250 \mathrm{~g}$ soil & & & & \\
\hline \multirow{3}{*}{ TSP } & $\mathrm{T} 1$ & $250 \mathrm{~g}$ soil & +4.85 & +4.85 & +2.47 & \\
\hline & $\mathrm{T} 2$ & $250 \mathrm{~g}$ soil & +3.64 & +3.64 & +1.85 & +10.34 \\
\hline & T0 & $250 \mathrm{~g}$ soil & & & & \\
\hline \multirow{3}{*}{ ERP } & E1 & $250 \mathrm{~g}$ soil & +7.95 & +4.85 & +2.47 & \\
\hline & E2 & $250 \mathrm{~g}$ soil & +5.96 & +3.64 & +1.85 & +13.00 \\
\hline & T0 & $250 \mathrm{~g}$ soil & & & & \\
\hline \multirow{2}{*}{ CIRP } & $\mathrm{C} 1$ & $250 \mathrm{~g}$ soil & +7.42 & +4.85 & +2.47 & \\
\hline & $\mathrm{C} 2$ & $250 \mathrm{~g}$ soil & +5.57 & +3.64 & +1.85 & +12.50 \\
\hline
\end{tabular}

\subsection{Pot Study}

The pot study was conducted at UPMKB. The experimental design was a completely randomized design (CRD) with four replicates. The size of each pot used was $22 \mathrm{~cm} \times 28 \mathrm{~cm}$ and each pot had $8 \mathrm{~kg}$ soil (based on soil bulk density). Maize (Zea mays L.) of the Hibrimas variety was used as test crop. The treatments evaluated were the same as those used in the incubation study. The soil moisture was maintained at $60 \%$ of field capacity.

A day before planting, $\mathrm{CZ}$ was mixed thoroughly with soil. Five seeds were sown and thinned to one plant per pot at seven days after sowing. The MOP $\left(60 \% \mathrm{~K}_{2} \mathrm{O}\right)$ and P fertilizers (TSP $46 \%$ $\mathrm{P}_{2} \mathrm{O}_{5}$, ERP $28 \% \mathrm{P}_{2} \mathrm{O}_{5}$, and CIRP 30\% $\left.\mathrm{P}_{2} \mathrm{O}_{5}\right)$ were surface applied, whereas urea $(46 \% \mathrm{~N})$ was buried in the soil to avoid loss of urea through ammonia volatilization. Split applications of the fertilizers were carried out on the 10th and 28th day after seeding (DAS). The maize plants were harvested at 
50 DAS (tasseling stage). The tasseling stage is the maximum growth stage of the plants before they go to a reproductive stage [29]. A day before harvest, soil samples were taken and analyzed for $\mathrm{pH}$, exchangeable cation, soil acidity, total $\mathrm{P}$, available $\mathrm{P}$, and inorganic $\mathrm{P}$ fractionation using standard procedures as described previously.

The harvested plants were partitioned into aboveground biomass (stems and leaves) and root. Afterwards, they were washed using tap water followed by distilled water before being oven dried at $60{ }^{\circ} \mathrm{C}$ until a constant weight was attained. Total dry weight of the maize plant (stem, leaves, and root) was recorded after which they were ground and analyzed for total P, P uptake, and P use efficiency. Total P of the plant tissues was extracted using the single dry ashing method [21] and determined using UV-VIS spectrometer after blue color development [22]. Total P uptake was determined by multiplying total $\mathrm{P}$ concentrations in the plant with the total dry weight of the plant, whereas $\mathrm{P}$ use efficiency (agronomic effectiveness) was determined by the formula shown below [30]:

$$
\text { Nutrient Use Efficiency }(\%)=\frac{[A-B]}{C} \times 100,
$$

where $\mathrm{A}=$ uptake with fertilizer, $\mathrm{B}=$ uptake without fertilizer, $\mathrm{C}=$ total amount of fertilizer that was applied; uptake $=$ nutrient concentration $(\%) \times$ dry weight $(\mathrm{g})$.

\subsection{Statistical Analysis}

Analysis of variance was used to detect treatment effects, whereas Tukey's test was used to compare treatment means at $p \leq 0.05$ using the statistical Analysis System (SAS) version 9.2.

\section{Results and Discussion}

This section is divided into subheadings to provide concise and precise descriptions of the experimental results, their interpretation, as well as the experimental conclusions that can be drawn.

\subsection{Characterization of Clinoptilolite Zeolite, Phosphorus Fertilizers, and Soil}

The CZ used in this study (granular form) was obtained from MB Plus Sdn. Bhd. Johore, Malaysia. The $\mathrm{pH}$ and $\mathrm{CEC}$ of the $\mathrm{CZ}$ were relatively high, 8.54 and $75.4\left(\mathrm{cmol}(+) \mathrm{kg}^{-1}\right)$, respectively (Table 3). The detail information on the surface morphology and elemental composition of the $\mathrm{CZ}$ used in this present study is mentioned in one of our published papers [31]. Elemental content of the P fertilizers is shown in Table 3.

Table 3. Selected phosphorus fertilizers and Clinoptilolite zeolite chemical properties.

\begin{tabular}{lcccc}
\hline \multicolumn{1}{c}{ Property } & TSP & ERP & CIRP & CZ \\
\hline $\mathrm{pH}($ water) & 2.46 & 7.42 & 7.93 & 8.54 \\
$\mathrm{CEC}\left(\mathrm{cmol}(+) \mathrm{kg}^{-1}\right)$ & $\mathrm{ND}$ & $\mathrm{ND}$ & $\mathrm{ND}$ & 75.4 \\
Total P $(\%)$ & 18.09 & 11.96 & 10.62 & 0.01 \\
Total $\mathrm{P}_{2} \mathrm{O}_{5}(\%)$ & 41.12 & 27.19 & 24.15 & $\mathrm{ND}$ \\
Total $\mathrm{K}(\%)$ & 0.42 & 0.25 & 0.31 & 0.37 \\
Total $\mathrm{Ca}(\%)$ & 4.88 & 47.55 & 51.73 & 0.67 \\
Total $\mathrm{Mg}(\%)$ & 0.35 & 0.17 & 0.24 & 0.10 \\
Total Fe $(\%)$ & 0.38 & 0.61 & 0.52 & 0.11 \\
\hline
\end{tabular}

Note: CEC is cation exchange capacity, TSP is triple superphosphate, ERP is Egypt rock phosphate, CIRP is Christmas Island rock phosphate, and ND is not determined.

Table 4 shows the selected physico-chemical properties of the Bekenu Series used. The soil was acidic $(\mathrm{pH}=4.32)$ and low in CEC $\left(5.33 \mathrm{cmol}(+) \mathrm{kg}^{-1}\right)$. The order of cations abundance was $\mathrm{Fe}>\mathrm{Al}>$ $\mathrm{Na}>\mathrm{Ca}>\mathrm{Mg}>\mathrm{K}$. The soil which was taken from an uncultivated area at UPMKB had slightly higher soil total carbon, exchangeable $\mathrm{K}, \mathrm{Ca}$, and $\mathrm{Mg}$ than the standard range noted by Paramananthan [32]. It could be due to litter decomposition with time on the soil surface. Dominated by more than $70 \%$ sand, 
this sandy loam soil is consistent with its inherent low fertility probably due to leaching of cations. Very low P availability (approximately $5 \%$ of soil total P) is similar to that of Gichangi et al. [33] who also reported that $85-90 \%$ of inorganic $\mathrm{P}$ added to tropical soils were unavailable to plants within the year of application. The initial inorganic $\mathrm{P}$ speciation of the soil was in the order of $\mathrm{Fe}-\mathrm{P}(68 \%)>$ Al-P $(13 \%)>$ Red-P $(10 \%)>$ Occl-P $(7 \%)>$ Ca-P $(2 \%)>$ Sol-P. Most of the P was immobilized within the crystalline and secondary minerals. The largest Pi fractions are associated with a high content of Fe-oxides, acidity, and advanced pedogenesis of the soil.

Table 4. Selected physico-chemical properties of the Bekenu Series.

\begin{tabular}{|c|c|c|c|c|c|}
\hline Soil Properties & $\begin{array}{c}\text { Value } \\
\text { Obtained }\end{array}$ & $\begin{array}{c}\text { Standard } \\
\text { Range }\end{array}$ & Soil Properties & $\begin{array}{c}\text { Value } \\
\text { Obtained }\end{array}$ & $\begin{array}{c}\text { Standard } \\
\text { Range }\end{array}$ \\
\hline $\mathrm{pH}$ (water) & 4.32 & $4.6-4.9$ & $\mathrm{CEC}\left(\mathrm{cmol}(+) \mathrm{kg}^{-1}\right)$ & 5.33 & $3.86-8.46$ \\
\hline Bulk density $\left(\mathrm{g} \cdot \mathrm{cm}^{-3}\right)$ & 1.01 & NA & Total Fe $\left(\mathrm{cmol}(+) \mathrm{kg}^{-1}\right)$ & 7.51 & NA \\
\hline Total P (mg.kg $\left.{ }^{-1}\right)$ & 49.96 & NA & Tot. acidity $\left(\mathrm{cmol}(+) \mathrm{kg}^{-1}\right)$ & 1.38 & NA \\
\hline Available P $\left(\mathrm{mg} \cdot \mathrm{kg}^{-1}\right)$ & 2.48 & NA & Exch. $\mathrm{Al}\left(\mathrm{cmol}(+) \mathrm{kg}^{-1}\right)$ & 0.9 & NA \\
\hline Organic matter $(\%)$ & 5.60 & $\mathrm{Nd}$ & Exch. $\mathrm{H}\left(\mathrm{cmol}(+) \mathrm{kg}^{-1}\right)$ & 0.48 & NA \\
\hline Total carbon (\%) & 3.25 & $0.57-2.51$ & Exch. $\mathrm{K}\left(\mathrm{cmol}(+) \mathrm{kg}^{-1}\right)$ & 0.24 & $0.05-0.19$ \\
\hline Texture & SL & SL & Exch. Ca $\left(\mathrm{cmol}(+) \mathrm{kg}^{-1}\right)$ & 0.76 & 0.01 \\
\hline Sand $(\%)$ & 74.84 & $72-76$ & Exch. $\mathrm{Mg}\left(\mathrm{cmol}(+) \mathrm{kg}^{-1}\right)$ & 0.45 & $0.07-0.21$ \\
\hline Silt (\%) & 12.67 & $8-9$ & Exch. Na $\left(\operatorname{cmol}(+) \mathrm{kg}^{-1}\right)$ & 3.60 & 0.01 \\
\hline Clay (\%) & 12.49 & $16-19$ & & & \\
\hline
\end{tabular}

Note: Standard range subjected to the soil development by Paramananthan. CEC is cation exchange capacity, NA is not available, SL is sandy loam. Tot. is total, whereas Exch. is exchangeable.

\subsection{Soil Total Phosphorus, Available Phosphorus, and Selected Soil Chemical Properties}

Soil total $\mathrm{P}$ and available $\mathrm{P}$ at 90 days after incubation (DAI) are presented in Figure 1a. Generally, application of $\mathrm{P}$ fertilizers regardless of $\mathrm{P}$ rate, $\mathrm{P}$ type, and $\mathrm{CZ}$ inclusion improved soil $\mathrm{pH}$, total $\mathrm{P}$, and available P. The significantly lower total $\mathrm{P}$ and available $\mathrm{P}$ observed in T2, C2, and E2 compared with T1, C1, and E1 was due to the lower amount of $\mathrm{P}$ fertilizers used. The increase in $\mathrm{pH}$ could have increased the negative charges on the soil particles because of dissociation of $\mathrm{H}^{+}$ions on the functional groups of organic matter, clay minerals, and precipitation of amorphous $\mathrm{Fe}$ and $\mathrm{Al}$ oxides and greater competition of hydroxyl ion $\left(\mathrm{OH}^{-}\right)$with phosphate ions for the adsorption sites [34]. An increase in acidic soil $\mathrm{pH}$ to slightly alkaline (7.30 to 7.60 ) is probably associated with precipitation of $\mathrm{P}$ with $\mathrm{Ca}$ (Table 5) and formation of significant insoluble Ca-P complexes (Table 6). Hence, this explains the significant decrease in total and available $\mathrm{P}$ with increasing soil $\mathrm{pH}$. Reduction in total acidity (Figure 1c) was only significant in the RP treatment. The insignificant effect of the RP treatments on soil titratable acidity could be due to the inactive displacement of $\mathrm{H}^{+}$and retention of basic cations by $\mathrm{CZ}$. Additionally, in this present incubation study, there were no plants to contribute to $\mathrm{H}^{+}$removal through uptake of nutrients. This is also evident in the soil exchangeable $\mathrm{Ca}$ as the effects of the treatments with $25 \%$ fertilizer reduction and recommended fertilizer rates on this cation were similar (Table 5). The contrast observation of total acidity in TSP treatment was due to its high solubility as affected by the acidulated process during manufacturing. Exchangeable $\mathrm{Al}$ (Figure 1c) in the soil were negligible, whereas exchangeable Fe (Table 5) significantly reduced with treatments application. This partly relates to the reactivity of $\mathrm{Al}$ and $\mathrm{Fe}$ which was retarded at neutral $\mathrm{pH}$ to form precipitation of exchangeable and soluble $\mathrm{Al}$ and $\mathrm{Fe}$ (insoluble $\mathrm{Al}$ and Fe hydroxides). Reduction in $\mathrm{Al}$ species solubility to a less soluble form with increasing soil $\mathrm{pH}$ is attributed to repeated deprotonation to form precipitate $[35,36]$. Limited availability of $P$ to satisfy sorption sites also explains the increase in soil exchangeable Fe with a reducing $\mathrm{P}$ fertilizer rate. In addition, significant sorption capacity of $\mathrm{Al}$ implies better saturation of $\mathrm{Al}$ compared with Fe [37,38]. 

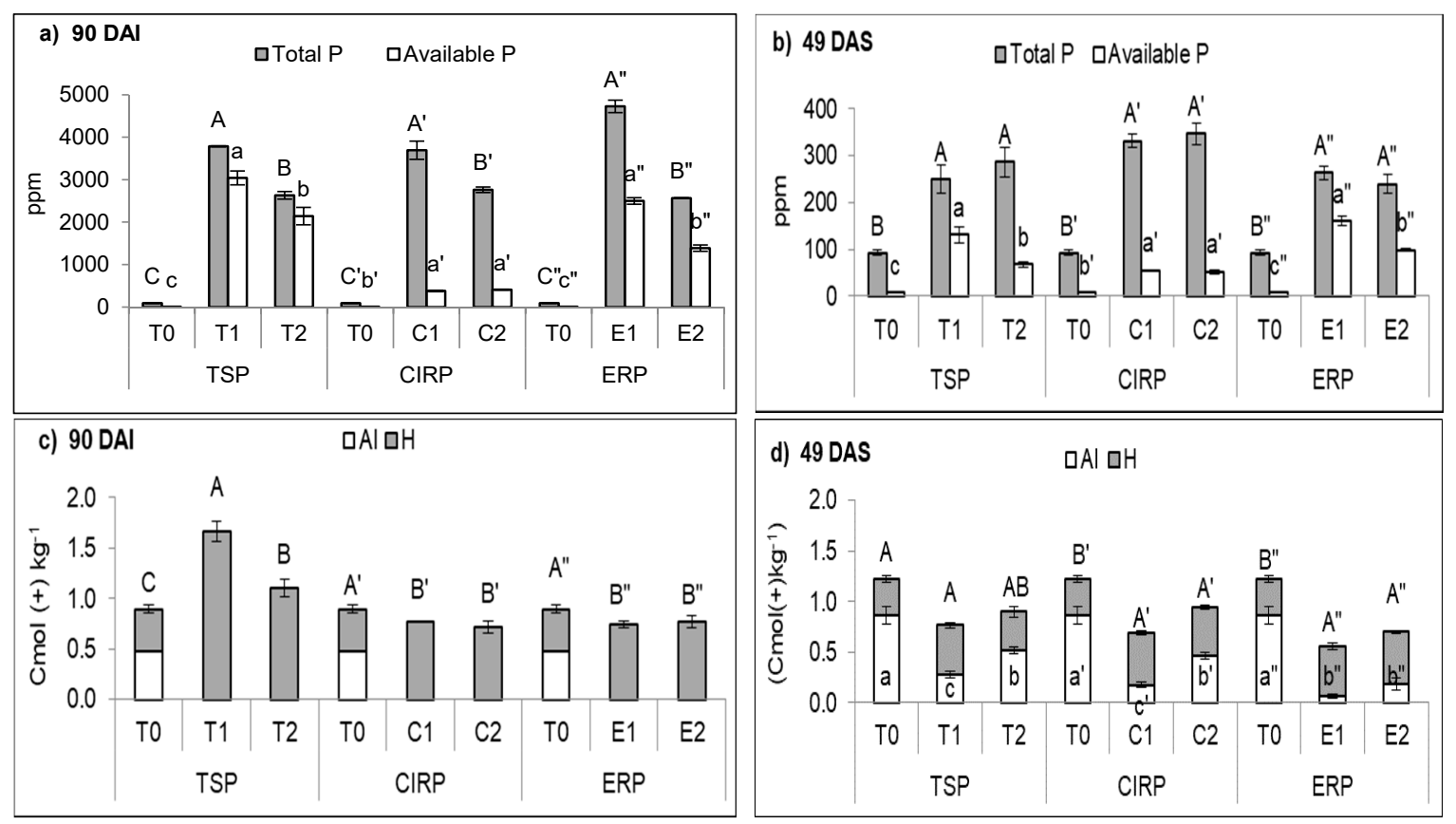

Figure 1. Effects of treatments on (a) soil total $\mathrm{P}$ and available P 90 days after incubation (DAI); (b) soil total P and available P at 49 day after seeding (DAS); (c) soil titratable acidity at 90 DAI, and (d) soil titratable acidity at 49 DAS. Means with a different letter indicate significant differences using Tukey's test at $p \leq 0.05$. Capital letters indicate titratable acidity, whereas small letters indicate $\mathrm{H}^{+}$. The error bars indicate the \pm standard error of triplicate.

Table 5. Selected chemical properties of soil at ninety days after incubation and forty-nine days after seeding.

\begin{tabular}{|c|c|c|c|c|c|c|c|c|c|}
\hline $\begin{array}{l}\text { Chemical } \\
\text { Properties }\end{array}$ & \multicolumn{3}{|c|}{ TSP } & \multicolumn{3}{|c|}{ ERP } & \multicolumn{3}{|c|}{ CIRP } \\
\hline \multicolumn{10}{|l|}{90 DAI } \\
\hline $\mathrm{pH}$ & $5.40 \mathrm{~b}$ & $7.36 a$ & $7.44 \mathrm{a}$ & $5.40 c^{\prime}$ & $7.36 b^{\prime}$ & $7.53 \mathrm{a}^{\prime}$ & $5.40 b^{\prime \prime}$ & 7.37a" & $7.47 a^{\prime \prime}$ \\
\hline \multicolumn{10}{|c|}{ Exch. Cation $\left(\mathrm{cmol}(+) \mathrm{kg}^{-1}\right)$} \\
\hline K & $0.19 \mathrm{c}$ & $14.64 \mathrm{a}$ & $9.51 b$ & $0.19 c^{\prime}$ & $15.16 a^{\prime}$ & $8.79 b^{\prime}$ & $0.19 c^{\prime \prime}$ & $17.13 a^{\prime \prime}$ & $9.26 b^{\prime \prime}$ \\
\hline $\mathrm{Mg}$ & $0.45 c$ & $1.57 \mathrm{a}$ & $1.39 \mathrm{~b}$ & $0.45 c^{\prime}$ & $0.66 b^{\prime}$ & $0.75 \mathrm{a}^{\prime}$ & $0.45 b^{\prime \prime}$ & $1.01 a^{\prime \prime}$ & $0.93 a^{\prime \prime}$ \\
\hline $\mathrm{Fe}$ & $2.21 \mathrm{a}$ & $0.72 b$ & $0.63 b$ & $2.21 a^{\prime}$ & $0.20 c^{\prime}$ & $0.22 b^{\prime}$ & $2.21 \mathrm{a}^{\prime \prime}$ & $0.30 c^{\prime \prime}$ & $0.31 b^{\prime \prime}$ \\
\hline \multicolumn{10}{|l|}{49 DAS } \\
\hline $\mathrm{pH}$ & $5.31 \mathrm{a}$ & $5.11 b$ & $4.98 \mathrm{~b}$ & $5.31 \mathrm{ab}^{\prime}$ & $5.46 a^{\prime}$ & $5.14 b^{\prime}$ & $5.31 a^{\prime \prime}$ & $5.49 a^{\prime \prime}$ & $5.56 a^{\prime \prime}$ \\
\hline \multicolumn{10}{|c|}{ Exch. Cation $\left(\mathrm{cmol}(+) \mathrm{kg}^{-1}\right)$} \\
\hline $\mathrm{Fe}$ & $1.05 \mathrm{a}$ & $0.79 b$ & $0.83 b$ & $1.05 a^{\prime}$ & $0.85 b^{\prime}$ & $0.88 b^{\prime}$ & $1.05 \mathrm{a}^{\prime \prime}$ & $0.73 b^{\prime \prime}$ & $0.81 b^{\prime \prime}$ \\
\hline
\end{tabular}

Means within row with different letters indicate significant difference using Tukey's test at $p \leq 0.05$. The ' \pm ' indicates standard error of quadruplicates, whereas Exch. is exchangeable. 
Table 6. Inorganic phosphorus speciation of soil at ninety days after incubation.

\begin{tabular}{llllllllll}
\hline \multirow{2}{*}{ Pi } & \multicolumn{3}{c}{ TSP } & \multicolumn{3}{c}{ ERP } & \multicolumn{3}{c}{ CIRP } \\
\cline { 2 - 10 } & \multicolumn{1}{c}{ T0 } & \multicolumn{1}{c}{ T1 } & \multicolumn{1}{c}{ T2 } & \multicolumn{1}{c}{ T0 } & \multicolumn{1}{c}{ E1 } & \multicolumn{1}{c}{ E2 } & \multicolumn{1}{c}{ T0 } & \multicolumn{1}{c}{ C1 } & C2 \\
\hline Sol-P & $0.1 \mathrm{c}$ & $309.5 \mathrm{a}$ & $146.6 \mathrm{~b}$ & $0.1 \mathrm{a}^{\prime}$ & $0.1 \mathrm{a}^{\prime}$ & $0.1 \mathrm{a}^{\prime}$ & $0.1 \mathrm{~b}^{\prime \prime}$ & $0.3 \mathrm{a}^{\prime \prime}$ & $0.1 \mathrm{~b}^{\prime \prime}$ \\
(ppm) & \pm 0.01 & \pm 12.38 & \pm 9.07 & \pm 0.01 & \pm 0.01 & \pm 0.01 & \pm 0.01 & \pm 0.03 & \pm 0.01 \\
Al-P & $3.6 \mathrm{c}$ & $1750.0 \mathrm{a}$ & $1103.3 \mathrm{~b}$ & $3.6 \mathrm{c}^{\prime}$ & $42.6 \mathrm{a}^{\prime}$ & $30.2 \mathrm{~b}^{\prime}$ & $3.4 \mathrm{c}^{\prime \prime}$ & $26.0 \mathrm{~b}^{\prime \prime}$ & $41.9 \mathrm{a}^{\prime \prime}$ \\
(ppm) & \pm 0.03 & \pm 42.02 & \pm 56.36 & \pm 0.03 & \pm 2.04 & \pm 2.60 & \pm 0.03 & \pm 0.27 & \pm 1.58 \\
Fe-P & $25.9 \mathrm{c}$ & $188.0 \mathrm{a}$ & $133 \mathrm{~b}$ & $25.9 \mathrm{a}^{\prime}$ & $11.0 \mathrm{~b}^{\prime}$ & $12.3 \mathrm{~b}^{\prime}$ & $25.87 \mathrm{c}^{\prime \prime}$ & $234.1 \mathrm{a}^{\prime \prime}$ & $143.6 \mathrm{~b}^{\prime \prime}$ \\
(ppm) & \pm 0.9 & \pm 2.1 & \pm 12.5 & \pm 0.89 & \pm 0.75 & \pm 0.13 & \pm 0.89 & \pm 10.66 & \pm 4.79 \\
Ca-P & $4.91 \mathrm{~b}$ & $108.1 \mathrm{a}$ & $105.3 \mathrm{a}$ & $4.91 \mathrm{~b}^{\prime}$ & $2122.5 \mathrm{a}^{\prime}$ & $2090.8 \mathrm{a}^{\prime}$ & $4.91 \mathrm{c}^{\prime \prime}$ & $1217.0 \mathrm{a}^{\prime \prime}$ & $595.7 \mathrm{~b}^{\prime \prime}$ \\
(ppm) & \pm 0.1 & \pm 1.3 & \pm 6.6 & \pm 0.1 & \pm 90.6 & \pm 102.6 & \pm 0.08 & \pm 40.08 & \pm 31.38 \\
Red-P & $0.7 \mathrm{ab}$ & $0.8 \mathrm{ab}$ & $0.9 \mathrm{a}$ & $0.7 \mathrm{c}^{\prime}$ & $3.2 \mathrm{a}^{\prime}$ & $2.9 \mathrm{~b}^{\prime}$ & $0.7 \mathrm{c}^{\prime \prime}$ & $2.3 \mathrm{a}^{\prime \prime}$ & $1.6 \mathrm{~b}^{\prime \prime}$ \\
(ppm) & \pm 0.04 & \pm 0.07 & \pm 0.07 & \pm 0.04 & \pm 0.10 & \pm 0.02 & \pm 0.04 & \pm 0.08 & \pm 0.05 \\
Occl-P & $2.7 \mathrm{c}$ & $10.7 \mathrm{~b}$ & $12.5 \mathrm{a}$ & $2.7 \mathrm{c}^{\prime}$ & $56.7 \mathrm{~b}^{\prime}$ & $79.1 \mathrm{a}^{\prime}$ & $2.71 \mathrm{c}^{\prime \prime}$ & $317.0 \mathrm{a}^{\prime \prime}$ & $169.6 \mathrm{~b}^{\prime \prime}$ \\
(ppm) & \pm 0.16 & \pm 0.34 & \pm 0.08 & \pm 0.16 & \pm 3.70 & \pm 3.90 & \pm 0.16 & \pm 5.25 & \pm 4.92 \\
\hline
\end{tabular}

Means within row with different letters indicate significant difference using Tukey's test at $p \leq 0.05$. The ' \pm ' indicates standard error of quadruplicates. Sol-P is loosely soluble $\mathrm{P}, \mathrm{Al}-\mathrm{P}$ is aluminum bound $\mathrm{P}, \mathrm{Fe}-\mathrm{P}$ is iron bound $\mathrm{P}, \mathrm{Ca}-\mathrm{P}$ is calcium bound $\mathrm{P}$, Red-P is reductant $\mathrm{P}$, and Occl-P is occluded $\mathrm{P}$. Pi-inorganic $\mathrm{P}$.

In the pot trial (49 DAS), the results of total $\mathrm{P}$ obtained were not consistent with those of the incubation study, but the trend of available P was similar (Figure 1b). A comparable soil total P of the treatment with 75\% fertilizer and CZ (T2, E2, and C2) with that of the recommended rate (T1, E1, and $\mathrm{C} 2$ ) regardless of the type of $\mathrm{P}$ fertilizer suggests the maize plant interaction with $\mathrm{CZ}$ assisted mineralization of soil organic P and dissolution of RPs. However, a considerable amount of P was unavailable to the maize plants due to $\mathrm{P}$ uptake and fixation. Moreover, part of the $\mathrm{P}$ released might have reacted with exchangeable $\mathrm{Ca}, \mathrm{Fe}$, and $\mathrm{Al}$ to form insoluble compounds. Thus, explaining the significant reduction of exchangeable $\mathrm{Ca}, \mathrm{Fe}$, and $\mathrm{Al}$ (Table 5). In addition, dissolution of the PRs is governed by an exchange-induced mechanism of the $\mathrm{CZ}$, and this explains the significantly lower soil exchangeable $\mathrm{Ca}$ (Table 5) in T2, E2, and C2 compared with those with a 100\% rate of fertilization and comparable soil total P contents (Figure 1b). Because of the soil-maize plant interaction in the pot trial, soil titratable acidity significantly reduced in the RPs treatments unlike with the TSP treatment. Soil exchangeable $\mathrm{Al}$ was available and soil exchangeable acidity $\left(\mathrm{H}^{+}\right)$(Figure 1d) significantly increased with treatments application. The afore-mentioned results were possible due to nitrification, root exudation, and active cations exchange activity of $\mathrm{CZ}$ cations with protons ions in the soil solution [7]. In addition, the significant availability of soluble $\mathrm{Al}$ regardless of treatment application is related to the failure to ameliorate acidic soil $\mathrm{pH}$. It has been reported in other studies that to increase $\mathrm{P}$ availability for plant use, higher rates of $\mathrm{P}$ fertilizers are required to saturate $\mathrm{P}$ sorption sites in soils $[39,40]$.

\subsection{Soil Inorganic Phosphorus Speciation}

The percentages of inorganic $P$ distribution at 90 DAI following application of TSP, ERP, and CIRP are summarized in Figure 2. Approximately $80 \%$ of inorganic $\mathrm{P}$ was occupied by active $\mathrm{P}$ fractions such as Fe-P, Al-P, and Ca-P in both 90 DAI and 49 DAS (T0) of soil alone (T0) whose Fe-P was the highest. The fractionations of the inorganic $\mathrm{P}$ pools were in the order of $\mathrm{Fe}-\mathrm{P}>\mathrm{Ca}-\mathrm{P}>\mathrm{Al}-\mathrm{P}>\mathrm{Occl}-\mathrm{P}>\mathrm{Red}-\mathrm{P}$ $>$ Sol-P in 90 DAI, whereas Fe-P $>$ Al-P $>$ Ca-P $>$ Occl-P $>$ Red-P $>$ Sol-P in 49 DAS. The dominance of $\mathrm{Fe}-\mathrm{P}$ fraction of soil alone (T0) is related to a lower $\mathrm{pH}$, higher content of $\mathrm{Fe}$, and the weathering processes of soils. These results corroborated with some findings on Ultisols [41,42] where Fe-P was the highest apart from indicating that the dynamics of $\mathrm{P}$, in particular $\mathrm{P}$ sorption, in agricultural soils is governed by colloidal Fe surfaces when soil $\mathrm{pH}$ is lower than $4.5[34,43-46]$. 


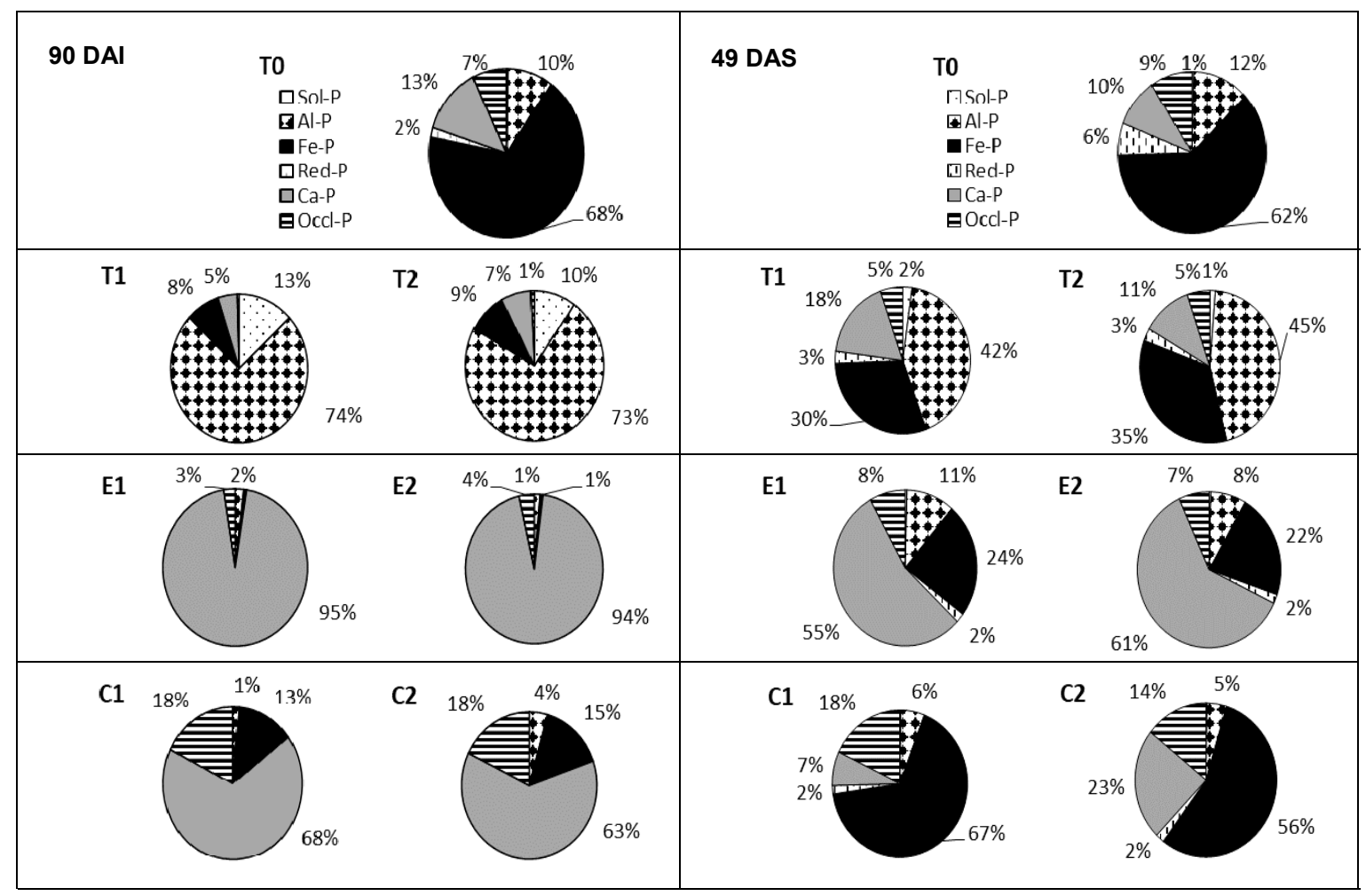

Figure 2. Percentages of inorganic $P$ speciation at 90 days after incubation and 49 days after seeding. Sol-P is loosely soluble $\mathrm{P}, \mathrm{Al}-\mathrm{P}$ is aluminum bound $\mathrm{P}, \mathrm{Fe}-\mathrm{P}$ is iron bound $\mathrm{P}, \mathrm{Ca}-\mathrm{P}$ is calcium bound $\mathrm{P}$, Red-P is reductant $\mathrm{P}$, and Occl-P is occluded P. T0-Soil alone, T1-triple superphosphate (TSP) at 100\%, T2-TSP 75\% + Clinoptilolite zeolite (CZ), C1-Christmas Island Rock phosphate (CIRP) at 100\%, C2-CIRP 75\% + CZ, E1-Egypt Rock phosphate (ERP) at 100\%, E2-ERP 75\% + CZ.

In general, the use of fertilizers in this incubation and pot trial regardless of $\mathrm{P}$ fertilizer type and rate altered the distribution of soil inorganic P differently. In the incubation trial, the TSP treatment at 90 DAI reduced the Fe-P fraction by six folds, whereas Al-P increased by seven folds (dominant inorganic P fraction) (Table 6 and Figure 2). This observation is, however, contrary to those of the soils with RPs as Ca-P was the dominant fraction regardless of the amount of RP. Application of ERP resulted in more than $90 \%$ Ca-P fraction, whereas CIRP showed $60 \%$ to $70 \%$ Ca-P regardless of the amount of RP used. The treatments with CZ (T2, E2, and C2) and fertilizer reduction showed a similar trend of those of the recommended rates of the fertilizers (T1, E1, and C1). At 49 DAS, T1 and T2 showed the highest Al-P fraction of $42 \%$ and $45 \%$, respectively. The treatments with ERP (E1 and E2) showed 55\% and 61\%, respectively of Ca-P followed by Fe-P and Al-P. For CIRP, Fe-P dominated followed by Ca-P > Occl-P > Al-P. The difference in the distribution of the P fraction was due to the different solubility of the fertilizers as they had different parent materials.

The TSP treatments showed a higher Al-P content compared with the RPs treatments (Figure 2 and Table 6), suggesting that a portion of the P of the TSP might have been adsorbed to the allophane and $\mathrm{Al}$ oxides of the soil at a faster rate than it was converted to other fractions. This observation is consistent with a report saying that Al-P varies with the rate of fertilization, high sesquioxides content, and low $\mathrm{pH}$ [47]. Thus, the relative increase in Al-P recovery following the use of TSP in this present study suggests the strong effect of fertilization on Al-P. The lower Al-P content recorded with RP treatments compared with TSP (Figure 2 and Table 6) was because rock phosphates are inherently composed of calcium apatite, which considerably increases Ca-P in soils [48]. As soil pH increased (Table 5), dissolution of RP was impeded by the 90 DAI. Moreover, the absence of a plant-soil association in this study could not significantly affect an exchange-induced mechanism for which $\mathrm{CZ}$ is noted of inducing RP dissolution. The higher Ca-P content in the RP treatments compared with TSP 
treatments suggests that the undissolved RPs dissolved slowly with time (Tables 6 and 7). The lower $\mathrm{Ca}-\mathrm{P}$ of the CIRP treatments indicates that the CIRP solubilizes faster than ERP. Regardless of the rate of $\mathrm{P}$ application, the reduction of $\mathrm{Ca}-\mathrm{P}$ with time could be related to the recovering of Sol-P in the TSP treatments as previously discussed. The afore-stated results are in agreement with the observation of Hongqing et al. [48] that dissolution of water soluble fertilizer (TSP) in acid soils produces Al-P and $\mathrm{Fe}-\mathrm{P}$ forms (active inorganic $\mathrm{P}$ fraction) as source (sink) of available $\mathrm{P}$ for plant uptake, whereas the RP application increases the $\mathrm{Ca}-\mathrm{P}$ fraction in soils because of their incomplete dissolution.

Table 7. Inorganic phosphorus speciation of soil at forty-nine days after seeding.

\begin{tabular}{cccccccccc}
\hline \multirow{2}{*}{ Pi Fraction } & \multicolumn{3}{c}{ TSP } & \multicolumn{3}{c}{ ERP } & \multicolumn{3}{c}{ CIRP } \\
\cline { 2 - 10 } & T0 & T1 & T2 & T0 & E1 & E2 & T0 & C1 & C2 \\
\hline Sol-P & $0.23 \mathrm{c}$ & $3.46 \mathrm{a}$ & $1.71 \mathrm{~b}$ & $0.23 \mathrm{~b}^{\prime}$ & $0.96 \mathrm{a}^{\prime}$ & $0.86 \mathrm{a}^{\prime}$ & $0.23 \mathrm{c}^{\prime \prime}$ & $0.69 \mathrm{~b}^{\prime \prime}$ & $0.98 \mathrm{a}^{\prime \prime}$ \\
(ppm) & \pm 0.02 & \pm 0.33 & \pm 0.11 & \pm 0.02 & \pm 0.11 & \pm 0.08 & \pm 0.02 & \pm 0.02 & \pm 0.11 \\
Al-P & $6.42 \mathrm{~b}$ & $66.43 \mathrm{a}$ & $62.10 \mathrm{a}$ & $6.42 \mathrm{c}^{\prime}$ & $24.54 \mathrm{a}^{\prime}$ & $19.14 \mathrm{~b}^{\prime}$ & $6.42 \mathrm{c}^{\prime \prime}$ & $18.65 \mathrm{a}^{\prime \prime}$ & $15.42 \mathrm{~b}^{\prime \prime}$ \\
(ppm) & \pm 0.58 & \pm 6.76 & \pm 2.51 & \pm 0.58 & \pm 1.40 & \pm 1.73 & \pm 0.58 & \pm 0.65 & \pm 0.60 \\
Fe-P & $33.42 \mathrm{a}$ & $47.27 \mathrm{a}$ & $47.27 \mathrm{a}$ & $33.42 \mathrm{~b}^{\prime}$ & $54.14 \mathrm{a}^{\prime}$ & $54.68 \mathrm{a}^{\prime}$ & $33.42 \mathrm{~b}^{\prime \prime}$ & $219.87 \mathrm{a}^{\prime \prime}$ & $204.40 \mathrm{a}^{\prime \prime}$ \\
(ppm) & \pm 1.49 & \pm 5.37 & \pm 4.43 & \pm 1.49 & \pm 0.91 & \pm 1.85 & \pm 1.49 & \pm 6.37 & \pm 11.78 \\
Ca-P & $3.15 \mathrm{a}$ & $4.16 \mathrm{a}$ & $3.35 \mathrm{a}$ & $3.15 \mathrm{~b}^{\prime}$ & $4.37 \mathrm{ab}^{\prime}$ & $4.91 \mathrm{a}^{\prime}$ & $3.15 \mathrm{~b}^{\prime \prime}$ & $6.22 \mathrm{a}^{\prime \prime}$ & $7.39 \mathrm{a}^{\prime \prime}$ \\
(ppm) & \pm 0.12 & \pm 0.46 & \pm 0.25 & \pm 0.12 & \pm 0.55 & \pm 0.36 & \pm 0.12 & \pm 0.33 & \pm 0.66 \\
Red-P & $5.60 \mathrm{c}$ & $27.67 \mathrm{a}$ & $16.90 \mathrm{~b}$ & $5.60 \mathrm{~b}^{\prime}$ & $124.27 \mathrm{a}^{\prime}$ & $146.85 \mathrm{a}^{\prime}$ & $5.60 \mathrm{c}^{\prime \prime}$ & $24.45 \mathrm{~b}^{\prime \prime}$ & $89.35 \mathrm{a}^{\prime \prime}$ \\
(ppm) & \pm 0.32 & \pm 3.87 & \pm 1.13 & \pm 0.32 & \pm 9.12 & \pm 12.41 & \pm 0.32 & \pm 2.57 & \pm 9.35 \\
Occl-P & $5.43 \mathrm{~b}$ & $8.48 \mathrm{a}$ & $7.80 \mathrm{a}$ & $5.43 \mathrm{~b}^{\prime}$ & $18.31 \mathrm{a}^{\prime}$ & $18.02 \mathrm{a}^{\prime}$ & $5.43 \mathrm{~b}^{\prime \prime}$ & $59.06 \mathrm{a}^{\prime \prime}$ & $56.26 \mathrm{a}^{\prime \prime}$ \\
(ppm) & \pm 0.09 & \pm 0.82 & \pm 0.91 & \pm 0.09 & \pm 1.21 & \pm 0.53 & \pm 0.09 & \pm 4.55 & \pm 0.81 \\
\hline
\end{tabular}

Means within row with different letters indicate significant difference using Tukey's test at $p \leq 0.05$. The ' \pm ' indicates standard error of quadruplicates. Pi is inorganic phosphorus , Sol-P is loosely soluble $\mathrm{P}, \mathrm{Al}-\mathrm{P}$ is aluminum bound $\mathrm{P}$, $\mathrm{Fe}-\mathrm{P}$ is iron bound $\mathrm{P}, \mathrm{Ca}-\mathrm{P}$ is calcium bound $\mathrm{P}$, Red-P is reductant $\mathrm{P}$, and Occl-P is occluded $\mathrm{P}$.

Table 6 shows inorganic P distribution at 90 DAI. The higher recovery of Sol-P in TSP treatments compared with those of the rock phosphates was due to the solubility of acidulated TSP. The higher content of Sol-P in T1 was due to the higher rate of TSP (normal fertilization which is $100 \%$ TSP), whereas the reduction of Sol-P in T2 is related to a reduction of TSP application by $25 \%$ of the recommended rate. The use of higher $\mathrm{P}$ rates reduced $\mathrm{P}$ fixation sites such that the $\mathrm{P}$ buffering capacity might have been exceeded. This partly explains the higher amount of Sol-P recovery following the application of TSP [49]. On the contrary, the RP treatments regardless of the fertilizer rate and CZ application showed no significant effect on Sol-P. The significant increase in soil $\mathrm{pH}$ and $\mathrm{Ca}^{2+}$ (Table 5) is related to the liming effect of the $\mathrm{CZ}$ and rock phosphate structure (Table 3), a process that reduces soil acidity by minimizing $\mathrm{Al}$ hydrolysis in acid soils (Figure 1c). A recent study revealed that zeolites are more effective in increasing soil $\mathrm{pH}$ than organic amendments [50]. Irrespective of the incubation and pot studies, loosely-soluble P was higher in the soil with TSP (Tables 6 and 7). This observation can be attributed to the higher solubility of TSP than with rock phosphates. Although Sol-P was lower in the RPs than in TSP and at 49 DAS, the Sol-P of E2 and C2 were comparable to those of $100 \%$ of ERP (E1) and CIRP (C1). This observation is consistent with a report that in high P fixing Ultisols, Al-P and Fe-P dominate following application of TSP (highly soluble P), whereas Ca-P dominates in soils upon RP application [48-51]. However, some heavily fertilized acid soils might have significant amounts of Ca-P [52] because hydroxyapatite is considered a product of the super-phosphates dissolution in acidic and slightly acidic soils [53]. Where there is soil-maize plant interaction (49 DAS), the use of CZ and RP in acid soils enhances $P$ release via an exchange-induced dissolution system, and the process is mediated by plants [11,12]. Moreover, uptake of cations from CZ liberates exchange sites which are occupied by $\mathrm{Ca}^{2+}$, thus lowering $\mathrm{Ca}^{2+}$ concentration in soil solution. This process might have induced further dissolution of RP to maintain P equilibrium. The dissolution of RP might have also been facilitated by a generation of $\mathrm{H}^{+}$through nitrification and root efflux. Plant roots also promote dissolution of RP through excretion of protons or through uptake of phosphate [54]. 
3.4. Plant Dry Matter Production, Phosphorus Concentration, Phosphorus Uptake, and Phosphorus Use Efficiency

The total plant dry matter production, $\mathrm{P}$ content in the maize plants, $\mathrm{P}$ uptake, and P use efficiency results are shown in Table 8. The poor dry matter production in T0 was as predicted because infertile soils are unable to sustain the growth and development of maize plants. However, the unfertilized maize plants (T0) showed a significantly higher nutrient content compared with those of the fertilized plants because of dilution effect. Higher nutrient concentration relates to poor growth and development of plants because nutrients translocation are poorer in unhealthy plants than in healthy plants [55]. The effects of the treatments with CZ (T2, C2, and E2) and those without the CZ (T1, C1, and E1) on dry matter production were similar and this indicates better nutrient retention and their timely release for the maize plant growth and development in spite of fertilizer reduction by $25 \%$. Perhaps CZ inclusion in the fertilization program induced better root growth and elongation. Thus, this lends to support the comparable P uptake and P use efficiency, although fertilizer application was reduced by $25 \%$ compared to the standard recommendation. Therefore, this indirectly suggests a possible reduction of the use of chemical fertilizers to avoid loss and environmental pollution. In other related studies, utilization of inorganic fertilizer in conjunction with zeolites also resulted in a timely release of cations. The zeolite structure temporarily enables nutrient retention, resulting in better nutrient uptake and use efficiency in Zea mays [41,56-58]. Apart from this, inclusion of zeolites in fertilization programs reduces the negative effects on soil acidity, prevents or minimizes soil erosion, increases cations storage capacity of soils, and leads to the building of precious humus complexes, hence, creating a favorable condition for microorganisms' growth and activity in soils, assisted timely release, efficient nutrient uptakes, and use efficiency $[41,59,60]$. Although in this study the effect of CZ on selected soil chemical properties was not glaring, a long-term application could result in a significant effect.

Table 8. Total dry matter production, total phosphorus concentrations, total phosphorus uptake, and phosphorus use efficiency in maize at fifty days after seeding.

\begin{tabular}{|c|c|c|c|c|}
\hline Treatment & $\begin{array}{l}\text { Total Dry Matter } \\
\quad\left(\mathrm{g}_{\text {plant }}{ }^{-1}\right)\end{array}$ & $\begin{array}{c}\text { Total P } \\
\text { Concentration (\%) }\end{array}$ & $\begin{array}{l}\text { Total P Uptake } \\
\quad\left(\mathrm{g} \mathrm{plant}^{-1}\right)\end{array}$ & $\begin{array}{c}\text { Total P Use } \\
\text { Efficiency (\%) }\end{array}$ \\
\hline \multicolumn{5}{|l|}{ TSP } \\
\hline T0 & $2.29 b$ & $0.61 \mathrm{a}$ & $0.005 \mathrm{~b}$ & - \\
\hline $\mathrm{T} 1$ & $49.58 \mathrm{a}$ & $0.54 \mathrm{ab}$ & $0.093 a$ & $8.93 a$ \\
\hline $\mathrm{T} 2$ & $47.57 \mathrm{a}$ & $0.41 b$ & $0.081 \mathrm{a}$ & $10.42 a$ \\
\hline \multicolumn{5}{|l|}{ CIRP } \\
\hline T0 & $2.29 \mathrm{~b}^{\prime}$ & $0.61 a^{\prime}$ & $0.005 b^{\prime}$ & - \\
\hline $\mathrm{C} 1$ & $32.93 a^{\prime}$ & $0.44 b^{\prime}$ & $0.049 a^{\prime}$ & $4.51 \mathrm{a}^{\prime}$ \\
\hline $\mathrm{C} 2$ & $37.48 a^{\prime}$ & $0.40 \mathrm{~b}^{\prime}$ & $0.050 a^{\prime}$ & $6.09 a^{\prime}$ \\
\hline \multicolumn{5}{|l|}{ ERP } \\
\hline T0 & $2.29 b^{\prime \prime}$ & $0.61 a^{\prime \prime}$ & $0.005 b^{\prime \prime}$ & - \\
\hline E1 & 34.99a" & $0.39 b^{\prime \prime}$ & $0.036 a^{\prime \prime}$ & $4.20 a^{\prime \prime}$ \\
\hline E2 & 31.49a" & $0.41 b^{\prime \prime}$ & $0.038 a^{\prime \prime}$ & $5.22 a^{\prime \prime}$ \\
\hline
\end{tabular}

Means within column with different letters indicate significant difference using Tukey's test at $p \leq 0.05$.

\section{Conclusions}

Effects of the treatments with $\mathrm{CZ}$ compared with the recommended fertilization on $\mathrm{P}$ fixation were similar. Treatments with TSP showed a lower dominance of Fe-P but more dominance in Al-P, whereas for RPs, Ca-P was pronounced in the incubation study. In the pot study, Al-P, Ca-P, and Fe-P were rather pronounced in the treatments with TSP, ERP, and CIRP, respectively. There was a decrease in exchangeable $\mathrm{Al}$ and soil titratable acidity because of the ability of $\mathrm{CZ}$ to increase soil $\mathrm{pH}$. Although the availability of $\mathrm{P}$ was not significant with the inclusion of $\mathrm{CZ}$ in the incubation study, dry matter production, $\mathrm{P}$ concentration, $\mathrm{P}$ uptake, and $\mathrm{P}$ use efficiency in the pot trial were comparable to that of 
the normal fertilization, suggesting that the $\mathrm{CZ}$ is beneficial and could be used to reduce $\mathrm{P}$ fertilizer requirement for Zea mays L. cultivation on acid soils. Regardless of the type of $P$ fertilizer, prevalence of the moderately labile $\mathrm{P}$ fractions (Al-P, Fe-P, and $\mathrm{Ca}-\mathrm{P}$ ) in both incubation and pot studies suggest that the $\mathrm{CZ}$ possibly acted as slow-release $\mathrm{P}$ sources to contribute to long-term $\mathrm{P}$ release. Further field trials on the potential of $\mathrm{CZ}$ in reducing chemical fertilization and its effects on soil and crop productivity are essential. It is also necessary to determine the economic benefits of including $\mathrm{CZ}$ in Zea mays L. cultivation.

Author Contributions: Conceptualization, N.A.H., O.H.A., and N.M.A.M.; methodology, N.A.H.; software, N.A.H.; validation, O.H.A. and N.M.A.M.; formal analysis, N.A.H.; investigation, N.A.H.; resources, O.H.A. and N.M.A.M.; data curation, N.A.H.; writing—original draft preparation, N.A.H.; writing-review and editing, O.H.A.; visualization, N.A.H.; supervision, O.H.A.; project administration, O.H.A.; funding acquisition, O.H.A. and N.M.A.M. All authors have read and agreed to the published version of the manuscript.

Funding: The authors gratefully acknowledge the financial support from the Ministry of Higher Education, Malaysia, Fundamental Research Grant Scheme (FRGS, vote number 5524983), Translational Research Grant (TRG 5526500), and Universiti Putra Malaysia for the collaborative research (Putra Grant, vote number 9622000).

Acknowledgments: The authors gratefully acknowledge the financial support from the Ministry of Higher Education, Malaysia, Translational Research Grant (TRG 5526500), Fundamental Research Grant Scheme (FRGS, vote number 5524983), and Universiti Putra Malaysia for the collaborative research (Putra Grant, vote number 9622000). Appreciation also goes to our administrative and technical support staff for providing materials used for the experiments and Universiti Malaysia Sabah for the publication cost.

Conflicts of Interest: The authors declare no conflict of interest.

\section{References}

1. Gikonyo, E.W.; Zaharah, A.R.; Hanafi, M.M.; Anuar, A.R. Evaluation of Phosphorus Pools and Fractions in an Acid Tropical Soil Recapitalized with Different Phosphorus Sources. Commun. Soil Sci. Plant Anal. 2008, 39, 1385-1405. [CrossRef]

2. Jalali, M.; Ranjbar, F. Aging effects on phosphorus transformation rate and fractionation in some calcareous soils. Geoderma 2010, 155, 101-106. [CrossRef]

3. Bondre, N. Phosphorus: How much is enough? Glob. Chang. 2011, 76, 14-17.

4. Filippelli, G.M. Phosphate rock formation and marine phosphorus geochemistry: The deep time perspective. Chemosphere 2011, 84, 759-766. [CrossRef] [PubMed]

5. Gilbert, N. Environment: The disappearing nutrient. Nature 2009, 461, 716-718. [CrossRef] [PubMed]

6. Cordell, D.; Drangert, J.-O.; White, S. The story of phosphorus: Global food security and food for thought. Glob. Environ. Chang. 2009, 19, 292-305. [CrossRef]

7. Ajirloo, G.S.; Jadid, A.P.; Nasirtabrizi, M.H. Effect of zeolite application on soil purification and some chemical properties of soil (case study). Tech. J. Eng. Appl. Sci. 2013, 3, 970-974.

8. Ramesh, K.; Reddy, D.D. Zeolites and Their Potential Uses in Agriculture. In Advances in Agronomy; Donald, L.S., Ed.; University of Delaware: Newark, NJ, USA, 2011; Volume 113, pp. 219-241.

9. Daković, A.; Tomašević-Čanović, M.; Rottinghaus, E.G.; Matijašević, S.; Sekulić, Ž. Fumonisin B1 adsorption to octadecyldimetylbenzyl ammonium modified clinoptilolite rich zeolitic tuff. Microporous Mesoporous Mater. 2007, 105, 285-290. [CrossRef]

10. Ming, D.W.; Allen, E.R. Use of natural zeolites in agronomy, horticulture, and environmental soil remediation. In Reviews in Mineralogy and Geochemistry; Ribbe, P.H., Ed.; Blacksburg Press: Blacksburg, VA, USA, 2001; Volume 5, pp. 619-653.

11. Allen, E.R.; Hossner, L.R.; Ming, D.W.; Henninger, D.L. Solubility and Cation Exchange in Phosphate Rock and Saturated Clinoptilolite Mixtures. Soil Sci. Soc. Am. J. 1993, 57, 1368-1374. [CrossRef]

12. Pickering, H.P.; Menzies, N.W.; Hunter, M.N.C. Zeolite/rock phosphate-A novel slow release phosphorus fertilizer for potted plant production. Sci. Hortic. 2002, 94, 333-343. [CrossRef]

13. Allen, E.; Ming, D.; Hossner, L.; Henninger, D.; Galindo, C. Growth and nutrient uptake of wheat in a clinoptilolite-phosphate rock substrate. Agron. J. 1995, 87, 1052-1059. [CrossRef] 
14. Lai, T.-M.; Eberl, D.D. Controlled and renewable release of phosphorous in soils from mixtures of phosphate rock and NH4-exchanged clinoptilolite. Zeolites 1986, 6, 129-132. [CrossRef]

15. Ramesh, K.; Biswas, A.K.; Somasundaram, J.; Rao, A.S. Nanoporous zeolites in farming: Current status and issues ahead. Curr. Sci. 2010, 99, 760-764.

16. Eberl, D.D. Controlled-Release Fertilizers Using Zeolites, U.S. Department of the Interior U.S Geological Survey. 1993. Available online: http://www.usgs.gov/tech-transfer/factsheets/94-066b.html (accessed on 5 January 2019).

17. Dixon, J.B.; Weed, S.B.; Parpitt, R.L. Minerals in Soil Environments. Soil Sci. 1990, 150, 562. [CrossRef]

18. Soil Survey Staff. Soil Survey of Larimer County, CO, U.S. USDA-NRCS Soil Survey; U.S. Gov. Print. Office: Washington, DC, USA, 2014.

19. Peech, M. Hydrogen-ion Activity. In Methods of Soil Analysis Chemical and Microbiological Properties; Black, C.A., Evans, D.D., White, J.L., Ensminger, L.E., Clark, F.E., Eds.; American Society of Agronomy: Madison, WI, USA, 1965; pp. 914-925.

20. Piccolo, A. Humus and soil conservation. In Humic Substances in Terrestrial Ecosystems; Piccolo, A., Ed.; Elseiver: Amsterdam, The Netherlands, 1996; pp. 225-264.

21. Tan, K.H. Soil Sampling, Preparation, and Analysis, 2nd ed.; CRC Press: Boca Raton, FL, USA, 2005.

22. Murphy, J.; Riley, J. A modified single solution method for the determination of phosphate in natural waters. Anal. Chim. Acta 1962, 27, 31-36. [CrossRef]

23. Cottenie, A. Soil testing and plant testing as a basis of fertilizer recommendation. Fao Soils Bull. 1980, 38, 70-73.

24. Mehlich, A. Determination of P, $\mathrm{K}, \mathrm{Na}, \mathrm{Ca}, \mathrm{Mg}$ and $\mathrm{NH} 4$; Soil Test Division Mimeo, North Carolina Department of Agriculture: Raleigh, NC, USA, 1953.

25. Rimmer, D.L.; Rodwell, D.L. Soil Science: Methods and Application. J. Ecol. 1995, 83, 352. [CrossRef]

26. Kuo, S. Phosphorus. In Methods of Soil Analysis. Part 3: Chemical Methods; Sparks, D.L., Ed.; Agronomy 9. The American Society of Anesthesiologists, Soil Science Society of America: Madison, WI, USA, 1996; pp. 869-920.

27. Rofiee, M.S. Involvement of CYP450 system in hepatoprotective activity of Malaysian Agricultural Research and Development Institute (MARDI)-produced virgin coconut oils. Afr. J. Pharm. Pharmacol. 2011, 5, 3-5. [CrossRef]

28. Ahmed, O.H.; Aainaa, H.N.; Majid, N.M.A. Zeolites to Unlock Phosphorus Fixation in Agriculture; Universiti Putra Malaysia: Serdang, Malaysia, 2017; p. 188.

29. Kasim, S.; Haruna, A.O.; Majid, N.M.A.; Yusop, M.K.; Jalloh, M.B. Effect of Organic Based N Fertilizer on Dry Matter (Zea mays L.), Ammonium and Nitrate Recovery in an Acid Soil of Sarawak, Malaysia. Am. J. Appl. Sci. 2009, 6, 1289-1294. [CrossRef]

30. Dobermann, A. Nitrogen use efficiency: State of the art. In Proceedings of the IFA International Workshop on Enhanced-Efficiency Fertilizers, Frankfurt, Germany, 28-30 June 2005; pp. 1-16.

31. Latifah, O.; Haruna, A.O.; Majid, N.M.A. Enhancing nitrogen availability from urea using clinoptilolite zeolite. Geoderma 2017, 306, 152-159. [CrossRef]

32. Paramananthan, S. Soils of Malaysia: Their Characteristics and Identification; Academy of Sciences Malaysia: Kuala Lumpur, Malaysia, 2000; Volume 1, pp. 11-125.

33. Gichangi, E.M.; Mnkeni, P.N.S.; Brookes, P.C. Effects of goat manure and inorganic phosphate addition on soil inorganic and microbial biomass phosphorus fractions under laboratory incubation conditions. Soil Sci. Plant Nutr. 2009, 55, 764-771. [CrossRef]

34. Naidu, R.; Syersy, J.K.; Tillman, R.W.; Kirkman, J.H. Effect of liming on phosphate sorption by acid soils. J. Soil Sci. 1990, 41, 165-175. [CrossRef]

35. Krstic, D.; Djalovic, I.; Nikezic, D.; Bjelic, D. Aluminium in Acid Soils: Chemistry, Toxicity and Impact on Maize Plants. In Food Production-Approaches, Challenges and Tasks; Aladjadjiyan, A., Ed.; InTech: Rijeka, Croatia, 2012; pp. 231-242. ISBN 978-953-307-887-8.

36. Azura, A.E.; Shamshuddin, J.; Fauziah, C.I. Root Elongation, Root Surface Area and Organic Acid by Rice Seedling under Al3+ and/or H+ Stress. Am. J. Agric. Boil. Sci. 2011, 6, 324-331. [CrossRef] 
37. Maguire, R.; Sims, J.; Coale, F.J. Phosphorus Solubility in Biosolids-Amended Farm Soils in the Mid-Atlantic Region of the USA. J. Environ. Qual. 2000, 29, 1225-1233. [CrossRef]

38. He, X.-T.; Traina, S.J.; Logan, T.J. Chemical Properties of Municipal Solid Waste Composts. J. Environ. Qual. 1992, 21, 318-329. [CrossRef]

39. Anetor, M.O.; Akinrinde, E.A. Lime effectiveness of some fertilizers in a tropical acid Alfisol. J. Cent. Eur. Agric. 2007, 8, 17-24.

40. Fageria, N.K.; Baligar, V.C.; Jones, C.A. Growth and Mineral Nutrition of Field Crops, 3rd ed.; CRC Press: Boca Raton, FL, USA, 2010.

41. Aainaa, H.N.; Ahmed, O.H.; Ab Majid, N.M. Effects of clinoptilolite zeolite on phosphorus dynamics and yield of Zea mays L. cultivated on an acid soil. PLoS ONE 2018, 13, e0204401. [CrossRef]

42. Paulos, D. Availability of phosphorus in the coffee soil of Southwest Ethiopia. In Soil the Resource Base for Survival, Proceedings of the 2nd Conference of Ethiopian Society of Soil Science (ESSS'93), 23-24 September 1993; Tekalign, M., Mitiku, H., Eds.; Ethiopian Society of Soil Science: Addis Ababa, Ethiopia, 1996; pp. 119-129.

43. Vaananen, R.; Hristov, J.; Tanskanen, N.; Hartikainen, H.; Nieminen, M.; Ilvesniemi, H. Phosphorus sorption properties in podzolic forest soils and soil solution phosphorus concentration in undisturbed and disturbed soil profiles. Boreal Environ. Res. 2008, 13, 553-567.

44. Gasparatos, D.; Haidouti, C.; Haroulis, A.; Tsaousidou, P. Estimation of Phosphorus Status of Soil Fe-Enriched Concretions with the Acid Ammonium Oxalate Method. Commun. Soil Sci. Plant Anal. 2006, 37, 2375-2387. [CrossRef]

45. Hamon, R.E.; McLaughlin, M.J. Interferences in the determination of isotopically exchangeable P in soils and a method to minimise them. Soil Res. 2002, 40, 1383-1397. [CrossRef]

46. Kanwar, J.S.; Grewal, J. Phosphorus Fixation in Indian Soils, New Delhi, India, 2nd ed.; Indian Council of Agricultural Research: New Delhi, India, 1990.

47. Nr, A.; Čakmak, D.; Saljnikov, E.; Roglic, G.; Koković, N.; Manojlović, D. Effect of waste Al-phosphate on soil and plant. Plant Soil Environ. 2013, 59, 130-135. [CrossRef]

48. Hongqing, H.; Chunying, T.; Chongfa, C.; He, J.-Z.; Xueyuan, L. Availability and residual effects of phosphate rocks and inorganic P fractionation in a red soil of Central China. Nutr. Cycl. Agroecosyst. 2001, 59, 251-258. [CrossRef]

49. Buresh, R.J.; Smithson, P.C.; Hellums, D.T.; Sanchez, P.A.; Calhoun, F. Building Soil Phosphorus Capital in Africa. In Soil Testing: Prospects for Improving Nutrient Recommendations; SSSA Special Publication No. 51; Soil Science Society of America: Madison, WI, USA, 2015; pp. 111-149.

50. Basri, M.H.; Junejo, N.; Abdu, A.; Hamid, H.A.; Kusno, M.A. Elevation and variability of acidic sandy soil pH: Amended with conditioner, activator, organic and inorganic fertilizers. Afr. J. Agric. Res. 2013, 8, 4020-4024.

51. Zoysa, A.; Loganathan, P.; Hedley, M.J. A technique for studying rhizosphere processes in tree crops: Soil phosphorus depletion around camellia (Camellia japonica L.) roots. Plant Soil 1997, 190, 253-265. [CrossRef]

52. Lookman, R.; Jansen, K.; Merckx, R.; Vlassak, K. Relationship between soil properties and phosphate saturation parameters a transect study in northern Belgium. Geoderma 1996, 69, 265-274. [CrossRef]

53. Kumar, V.; Gilkes, R.; Armitage, T.M.; Bolland, M.D.A. Identification of residual P compounds in fertilized soils using density fractionation, $\mathrm{X}$-ray diffraction, scanning and transmission electron microscopy. Nutr. Cycl. Agroecosyst. 1994, 37, 133-149. [CrossRef]

54. Hinsinger, P.; Gilkes, R. Dissolution of phosphate rock in the rhizosphere of five plant species grown in an acid, P-fixing mineral substrate. Geoderma 1997, 75, 231-249. [CrossRef]

55. Martin, M.H.; Marschner, H. The Mineral Nutrition of Higher Plants. J. Ecol. 1988, 76, 1250. [CrossRef]

56. Aainaa, H.N.; Haruna, A.O.; Kasim, S.; Majid, N.M.A. Reducing Egypt Rock Phosphate Use in Zea mays Cultivation on an Acid Soil Using Clinoptilolite Zeolite. Sustain. Agric. Res. 2014, 4, 56. [CrossRef]

57. Rabai, K.A.; Kasim, S.; Ahmed, O.H. Use of formulated nitrogen, phosphorus, and potassium compound fertilizer using clinoptilolite zeolite in maize (Zea mays L.) cultivation. Emir. J. Food Agric. 2013, 25, 713. [CrossRef]

58. Ahmed, O.H.; Sumalatha, G.; Majid, N.M.A. Use of zeolite in maize (Zea mays) cultivation on nitrogen, potassium, and phosphorus uptake and use efficiency. Int. J. Phys. Sci. 2010, 5, 2393-2401. 
59. Grant, C.; Bittman, S.; Montreal, M.; Plenchette, C.; Morel, C. Soil and fertilizer phosphorus: Effects on plant P supply and mycorrhizal development. Can. J. Plant Sci. 2005, 85, 3-14. [CrossRef]

60. Beqiraj, E.; Gjoka, F.; Muller, F.; Baillif, P. Use of zeolitic material from Munella region (Albania) as fertilizer in the sandy soils of Divjaka region (Albania). Carpathian J. Earth Environ. Sci. 2008, 3, 33-47.

(C) 2020 by the authors. Licensee MDPI, Basel, Switzerland. This article is an open access article distributed under the terms and conditions of the Creative Commons Attribution (CC BY) license (http://creativecommons.org/licenses/by/4.0/). 